\title{
Article \\ Decision-Making under the Risk, Uncertainty and COVID-19 Pandemic Conditions Applying the PL9A Method of Logistics Planning-Case Study
}

\author{
Wiesław Staniuk $^{1}$, Michał Staniuk ${ }^{1, *}$, Norbert Chamier-Gliszczynski ${ }^{2}$, Marianna Jacyna ${ }^{1}$ (D) \\ and Michał Kłodawski ${ }^{1, *(1)}$ \\ 1 Faculty of Transport, Warsaw University of Technology, 00662 Warsaw, Poland; w.staniuk@sterlog.pl (W.S.); \\ marianna.jacyna@pw.edu.pl (M.J.) \\ 2 Faculty of Mechanical Engineering, Koszalin University of Technology, 75453 Koszalin, Poland; \\ norbert.chamier-gliszczynski@tu.koszalin.pl \\ * Correspondence: m.staniuk@sterlog.pl (M.S.); michal.klodawski@pw.edu.pl (M.K.)
}

Citation: Staniuk, W.; Staniuk, M.; Chamier-Gliszczynski, N.; Jacyna, M.; Kłodawski, M. Decision-Making under the Risk, Uncertainty and COVID-19 Pandemic Conditions Applying the PL9A Method of Logistics Planning-Case Study. Energies 2022, 15, 639. https:// doi.org/10.3390/en15020639

Academic Editors:

Jarosław Witkowski and

Maja Kiba-Janiak

Received: 9 December 2021

Accepted: 13 January 2022

Published: 17 January 2022

Publisher's Note: MDPI stays neutral with regard to jurisdictional claims in published maps and institutional affiliations.

Copyright: (c) 2022 by the authors. Licensee MDPI, Basel, Switzerland. This article is an open access article distributed under the terms and conditions of the Creative Commons Attribution (CC BY) license (https:// creativecommons.org/licenses/by/ $4.0 /)$.

\begin{abstract}
The next industrial revolution, which coincided with the COVID-19 pandemic, is prompting a different look at the issue of supply chain change management. A new perspective should take into account the aspect of supply chain efficiency at multiple levels. Efficient logistics is green and energy-saving, both of which need to be systematically integrated with the logistical planning processes. The dynamic changes on the demand and supply side resulting from social, political, and economic transformations have significantly influenced the shaping of long-term supply chains. The development of new manufacturing and logistics technologies prompts the development and implementation of new integrated planning methods to support supply chain management processes. Modern supply chains are oriented towards operations in a dynamically changing socio-economic environment. The new methods are capable of incorporating dynamic adaptation of logistics infrastructure which respond to changing relationships between supply and demand. To meet the identified problems of complexity, relevance, and time-consumption of the logistic planning process in modern enterprise management, the PL9A method of logistic planning and 9A LOGPLANNER application for logistics planning were developed. The article presents the results of experimental and simulation studies on the improvement of logistic processes in a working manufacturing enterprise with application of the PL9A method. The results of the experimental work indicate that the application of the PL9A method embedded in the 9A LOGPLANNER software makes it possible to dynamically simulate any number of logistics system variants in a short period of time, while reducing risk and obtaining tangible benefits in terms of energy and ecological efficiency.
\end{abstract}

Keywords: COVID-19; logistics planning; management; supply chain management; dynamic lanning

\section{Introduction}

According to the definition [1], supply chain management is a process related to the management of material flows within a supply chain to maximize its global profitability. As such supply chain management comprises the overall processes involved in handling the streams of goods resulting from the existence of the supply and demand laws. Supply chains that fit into the Industry 4.0 concept are subject to re-engineering processes in the direction of e-commerce logistics. Undoubtedly the advantage of such a strategy is the ability to quickly expand in global markets, but it requires partners to improve management methods, including planning focused on the efficiency of logistics activities. The dynamic changes in the market caused by the COVID-19 pandemic as well as a new look at the aspects of energy efficiency and environmental protection have introduced new elements of risk into the traditional planning model, making supply chain management increasingly complex. The dynamics of changes on the supply and demand side and the emergence 
of new risks require new studies and continuous analysis including the development of methods for logistics resource management. An innovative approach to the planning process could take into account modeling of correlations between the accumulation of capital, resources, and changes in demand and supply, ecological factors, and energy efficiency. Achieving excellence in logistics planning processes cannot be done without the use of Big Data analytics [2,3] and reduction of the tendency of organizations to make high-risk decisions.

Risk seeking, inconsistent management, erroneous analytical tools can all contribute towards sub-optimal decision making. Decision-making without taking into account the effectiveness of the logistics system, and the availability of resources may cause disruptions in the streams of goods and capital, and ultimately limit the performance of the logistics system. Establishing logistics planning on a technological and process-focused approach towards accumulated logistics resources may, in turn, improve the overall quality of the planning process and significantly reduce the labor intensity and the development period.

The development of an innovative management method requires the characterization of the basic premises. However, the development of an innovative management method needs to begin from the very beginning. Cooperation within open supply chains and the dynamics of processes shaping them, including changes on the demand and supply side, require companies to apply solutions allowing an organized and systematized performance of analytical steps which ensures repeatability and accuracy. The currently available Enterprise Resource Planning (ERP) systems provide the means of easing communication by reducing the workload of registration, report, and management processes. Simultaneously, the ERP systems provide managers with integrated metadata representing real-time economic processes and events. This enhances the effectiveness of achieving business goals by providing organizations with the possibility of identifying barriers, targeting internal and external supply chain constraints [4]. The most common example of such constraint is the limited ability to respond to short-term changes [5] in supply and demand, and the ability to shape the size and suitability of the company's logistics assets concerning these changes.

To meet the requirements of Industry 4.0 [6], Logistics 4.0 [7], and companies faced with the need to adapt to supply chain changes, which include operational planning associated with their deployment in the logistics system, the PL9A method of logistics planning was developed. The PL9A method includes establishing new economic relationships for the newly designed logistics system including criteria of energy efficiency and eco-efficiency. This article discusses the PL9A method, its applicability, and its effects.

The purpose of the article is to present the applicability of the PL9A method of logistics planning under conditions of uncertainty and COVID-19 pandemic. In Section 1 authors presents the impact of COVID-19 pandemic on modern supply chains and short term planning. Section 2 is devoted to the planning process issues, the requirements for logistical planning and the applied methods. Section 3 presents the results of the literature analysis on the subject of logistical planning. Section 4 is devoted to the presentation of the PL9A logistics planning method, including assumptions and the planning process. Section 5 includes a case study and a presentation of experimental study results based on data obtained from an existing enterprise. Section 6 focuses on the conclusions regarding logistics planning and results of experimental works.

\section{The Logistics Planning Process in Business Operations}

Strategic planning processes cover all the activities of an enterprise, including the analysis of the market situation. In enterprises, the strategic document is based on economic data and figures. An approved document includes a financial plan covering an annual budgeting period, effectively making it the most important planning document in the company.

The duration of the planning process in the long term of a business cycle and the market stability of a company may seem irrelevant. However, as 2020 showed, a one-year planning period can be excessive. In a period in which the determinant of change was the 
emergence and spread of COVID-19, the demand- and supply-side changes affected all industries and global supply chains were disrupted. As a result, the speed and efficiency of change implementation gained increasing significance and value. In such a dynamically changing logistics system, decisions may be based on incomplete data as well as the intuition of the decision-maker. In case of unforeseen, new deterministic factors creating changes on the demand and supply side, the integrated planning supported by Information Technology (IT) can have a positive effect on decision-making in an environment of high uncertainty and risk.

In practice, the planning process in medium-sized enterprises lasts one calendar quarter. The process usually concludes with the approval of the strategic plan and operational plans. This period is followed by an annual period of verification of assumptions and objectives adopted in the planning process, as well as the assessment of its implementation. The evaluation process is carried out based on examining the balance sheet-financial results from the profit and loss account. The assessment of the implementation of the strategic and operational plan allows identifying the effects of economic decisions and actions taken concerning the market situation resulting from changes in demand and supply. The awareness of market changes occurring on the demand and supply side may be a key moment for the decision to develop new strategic and operational plans for the company.

A survey of methods and tools used in logistic planning processes conducted during the TRENDOWNIA 2020 logistics conference showed that for 100\% of 148 respondents the basic tool used in logistic planning is a spreadsheet. This claim of practitioners was also substantiated by the results of a study conducted in 2016 by the author of a publication [8], which confirms the use of the Excel spreadsheet in modeling and simulations performed by business professionals. The spreadsheet is the most common tool for conducting quantitative and qualitative analyses and is a recognized tool in modeling multi-variant scenarios for budgets and operational plans. The range of data necessary to carry out logistical planning processes in the area of strategic activities seems to be wider than the potential and possibilities of ERP class systems.

The current stage of development of global economies and global supply chains called the fourth industrial revolution (Industry 4.0 [9]) and presented by UNITY in the form of Industry 4.0 Roadmap: Logistics [10] describes a company's logistics system in a sequence of changes oriented towards achieving an economic goal resulting from synergic action within the supply chain. Achieving synergy requires the involvement of the right resources at the right time and with the right efficiency. As a rule, the reaction should respond to incoming signals or alterations from the external environment. However, evaluating the logistics system of an enterprise in terms of its level of adaptation and the Industry 4.0 concept presented by UNITY remains challenging. In the absence of established methods of assessing enterprises in terms of their compatibility with the Industry 4.0 concept, it is currently impossible to determine at which stage of development a company is. This challenge becomes clearer when comparing the variability of objectives, results, and effects of company management concerning the demand and the enterprise's market share (Figure 1).

Assuming that the result of an action is the result of the adopted plan and the company's ability to effectively adjust the used resources in response to changes occurring on the demand and supply side. The graph presented above shows a graphic presentation of the results and effects of planning activities in operational activities at all levels of the organization concerning changes in the socio-economic space, including the presence of extraordinary events.

One such event, which triggered several changes in global supply chains, was the COVID-19 pandemic in 2020, for which some managers were not prepared. Scenarios were not rehearsed and decisions made were often questionable or even wrong. The correction scenarios and plans developed in 2019 were extensively verified in practice. A drop in sales, breakdown or interruption of the supply chain, and a change in the availability of goods or commodities required many changes covering all processes occurring in supply chain. 
These changes included the reconfiguration of the logistics system in terms of its capacity, structure of inventories, their size as well as improving process efficiency, addressing the suitability and availability of infrastructure elements. In such circumstances, the criteria for assessing energy and environmental performance were marginalized or even omitted from the assessment. The question arises whether the process of reconfiguration of the logistics system can be effectively carried out with tools for which the cycle of study of conclusions and confirmation of planned actions lasts a quarter, and the results of actions will be known after three quarters.

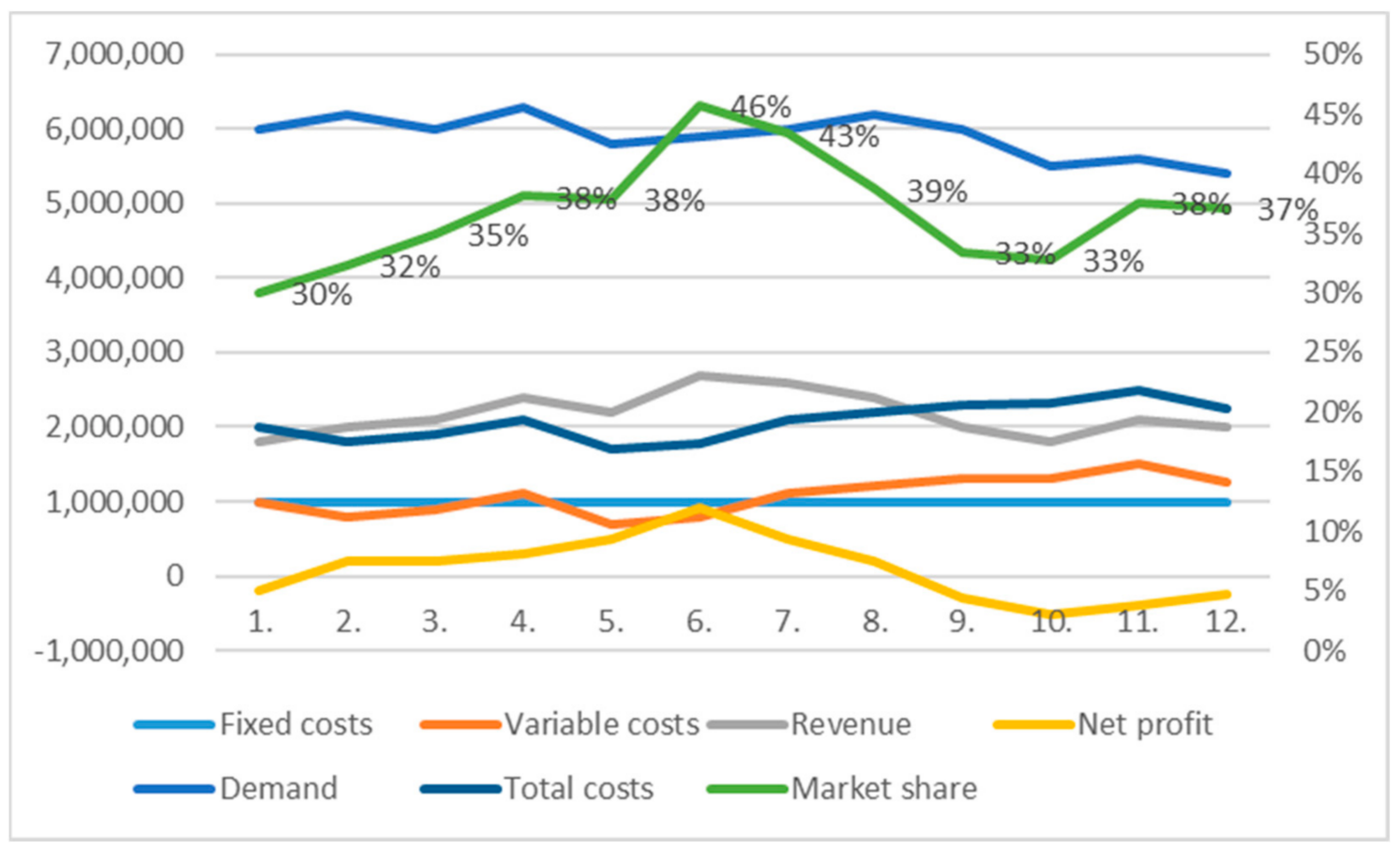

Figure 1. Key performance indicators of the economic evaluation of the company. Own study based on data of a company listed on the stock market.

In a crisis management situation characteristic of the COVID-19 pandemic, processes lasting a quarter must be considered low-value, uncertain, and of doubtful value in terms of outcome. However, with no other planning methods and tools at our disposal, such time-frames need to be treated as optimal from the perspective of resources, instruments, and methods available to a modern manager. Provided that logistic data is aggregated in time series, their underlying processes are mapped and IT tools capable of supporting logistic modeling and planning, an innovative planning process, shortening the study cycle to a weekly period can be applied.

A dynamic Industry 4.0 market-oriented enterprise operating in a competitive market with independent demand, where volatility and vulnerability are a constant, should be adaptable to:

- demand-side changes,

- supply-side changes,

- macroeconomic system changes,

- legal system changes,

- socio-economic system changes,

- the occurrence of exceptional events.

A company that accepts process-based dynamics and complexity has the potential for a reactive response towards real-time events, provided it operates based on an integrated planning system. 
Advancing globalization, changes in the economic system, business cycles, and sociopolitical transformations contributed towards open supply chain management. In general, all processes related to the management of streams of goods flowing from the supply side to the demand side fall under supply chain management [11,12]. In a manufacturing enterprise [13], logistics planning is a structured process covering all its activities related to planning, economic, business, and operational decision-making, including changes in:

- $\quad$ specifications of product manufacturing processes,

- the main manufacturing processes [14,15] and supporting processes,

- changes on the supply and demand side,

- $\quad$ changes in the legal and macroeconomic environment of the company, determining market conditions on the economics of production,

- changes in production technology,

- $\quad$ occurrence of random events with significant impact on demand and supply as well as security and continuity of operations, including the occurrence of extraordinary events,

- changes in the distribution and supply system related to changes in the distribution network or supply chain.

One of the proposals for improving the planning process is digitalization and the reliance on cloud computing. However, data digitalization itself does not guarantee satisfying results. It is also worth noting the risk related to the paradox of IT productivity occurring during the implementation of new IT technologies [16,17]. From the managers perspective, the high productivity of IT [18] is not so obvious and certain. Productivity benefits arise only when IT enables tasks to be performed in new innovative ways [17].

Considering the aspect of logistics planning, various methods of logistics planning have become widespread in practice, i.e.:

- planning methods according to the theory of constraints (TOC), e.g., Drum Buffer Rope,

- planning methods using the APS system-Advanced Planning and Scheduling (APS),

- $\quad$ logistics planning according to Association for Supply Chain Management (APICS) standards,

- Material Resource Planning (MRP I),

- Manufacturing Resource Planning (MRP II),

- $\quad$ planning with demand forecasting Demand Management (DEM),

- production process planning according to REFA,

- methods and tools for order execution planning,

- $\quad$ production resources planning.

\section{The Literature Analysis}

The study and analysis of publications on logistics planning methods and tools used as well as interviews with experts, practitioners representing companies managing global supply chains. The available methods of logistical planning are characterized by high labor intensity and relatively low accuracy of results. This is also confirmed by the research on the effectiveness of implementing changes in production, conducted and described in a study by PWC [17], the results of which are presented in Table 1.

High investment outlays, the lack of a clear vision and support from the management, limited or absence of cooperation with business partners, and unclear economic benefits resulting from computerization are the key factors determined by the PWC survey $[17,19]$. However, energy efficiency and ecology are not defined as a barrier to company development. This indicates a lack of awareness of the importance of energy efficiency and ecology for the effectiveness of the enterprise integration process. Independently, gaps in management and planning were cited as the main causes of developmental barriers, indicating the need for improving integrative management methods [8]. 
Table 1. Results of the study on barriers affecting the effectiveness of the implementation of change in manufacturing.

\begin{tabular}{ccc}
\hline No. & Barrier & Results \\
\hline 1. & High investment cost (financial aspect) & $46 \%$ \\
2. & Lack of a clear support vision from management & $33 \%$ \\
3. & No cooperation with business partners in terms of digital solutions & $30 \%$ \\
4. & Unclear economic profits from digital investments & $28 \%$ \\
5. & Unresolved data security issues and privacy of external data & $28 \%$ \\
6. & Slow expansion of the basic infrastructure technology & $26 \%$ \\
7. & Lack of training and digital skills & $24 \%$ \\
8. & Fear of losing control over intellectual property & $15 \%$ \\
9. & Unqualified workforce & $4 \%$ \\
10. & Lack of digital standards, norms and certificates & $4 \%$ \\
\hline
\end{tabular}

An in-depth analysis of the literature [20] on the study of barriers to the integration of enterprises in supply chains [21] covered the period 1993-2018 and involved a group of 36 authors and their publications. A total of 204 barriers were identified.

The analysis of publications devoted to the study of the problematic barriers in the integration of enterprises cooperating in supply chains made it possible to identify 11 barriers that, according to the authors, should be classified as critical. The results of the analysis are presented in Table 2.

Table 2. Most commonly stated barriers in supply chain company integration.

\begin{tabular}{|c|c|c|}
\hline Barrier Type & Number of Barriers & Publications \\
\hline Technological barriers & 61 & {$[22-42]$} \\
\hline Human barriers & 44 & {$[27-30,32-34,36,40,41,43-51]$} \\
\hline Management and economic process barriers & 44 & {$[26,28-31,33-37,39-41,44,46,52,53]$} \\
\hline Management barriers & 14 & {$[26-29,40,41,44,46,47,52-54]$} \\
\hline Legal barriers & 9 & {$[29,30,36]$} \\
\hline IT implementation barriers & 9 & {$[26,30,34,36,38,55]$} \\
\hline External scientific barriers & 8 & {$[40,49,56]$} \\
\hline Communication and goal-orientation barriers & 6 & {$[26,34,49]$} \\
\hline External barriers & 6 & \\
\hline Barriers in data-based analytical methods & 2 & {$[26,34]$} \\
\hline Internal risk & 1 & [34] \\
\hline
\end{tabular}

Apart from IT [57] methods and solutions, the improvement of planning processes in logistics $[58,59]$ can be seen in the quality of planning processes and data, especially those involving teams of managers, specialists, and consultants for weeks or even months. Labor-intensive planning processes, together with the expected high precision and accuracy of decisions affecting future results and effects, carried out under time pressure and the need for multivariate modeling, are a practical challenge, a real phenomenon and belong to the area of practice of every manager.

Ensuring high quality and precision in the planning process should be consistent with the 7R logistics canon and include the identification and study of logistical resources, study of market changes on the demand and supply side, study and planning of flowing streams of goods and capital, assessment of risks affecting the process of plan implementation and its course, assessment of economic efficiency and feasibility of implementation of the operational efficiency plan, and assessment of energy and environmental efficiency.

In order to illustrate the logistic processes taking place in companies with a logistic business orientation, the logistic processes are presented in a phase approach in Figure 2. 


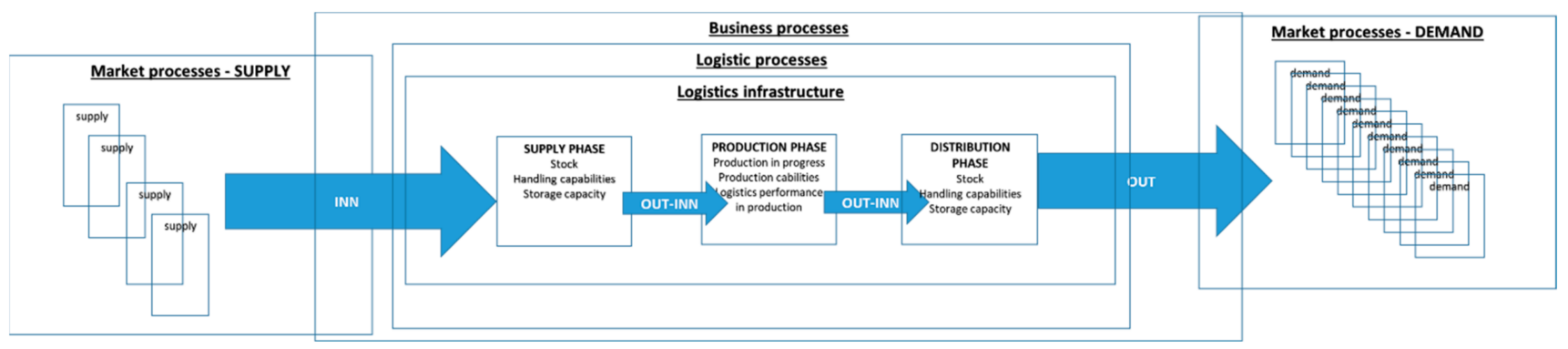

Figure 2. Graphical presentation of the logistics system model in phase proceseses.

Considering the quality of the planning process and its relationship to production [60,61], it seems reasonable to isolate organizational units specializing in an integrated and process approach to processing information [3] and goods flow between the supply, production, and distribution phases. This can provide a needed innovation such as a restricted unit dealing with a well-defined set of tasks.

It is also worth paying attention to the determinants of processes covered by the term specificity". This term referring to production processes often covers constraints, requirements resulting from technology, environmental conditions of the process as well as results and requirements resulting from the adopted strategic and operational plans. The results of the assessment of the suitability and availability of process infrastructure elements often fall within this term.

Ensuring the effectiveness of plan implementation requires ensuring the availability of resources. Estimating the required resources needs to be assessed by considering the infrastructural suitability of the storage capacity, internal transport [62], and supply. This assessment should be evaluated against the requirements of the plan. During the implementation period, the adopted plan is prone to change due to random events, the study, analysis, and evaluation is to relate to the assessment of all the company's resources. The logistics planning process for separate production structures should include production volume, availability of production resources, inventory volume and availability, spatiotemporal harmonization, and synchronization of deliveries concerning the adopted production plan.

For planning production processes, the deterministic factors are warehouse $[63,64]$ and acquisition processes into account their adaptability in response to changes [65]. An additional factor that may be taken into account in the planning process is the possibility of organizing production processes based on synchronous production, but also ecological $[66,67]$ and energy-saving [68] production. Production management in such a changeable environment encourages the search for technical and organizational solutions that can be applied in practice.

The mixed method of transport planning covering an adaptive strategy deserves attention [69]. Although it focuses on transport processes [70], it can be referred to as the method of logistics planning. The approach to solving the problem of evaluating planning processes in logistics [71] seems to be consistent with the concept of transport strategy according to the mixed method described by the author [69]:

- combining multiple approaches in all phases of the research (defining the research problem, collecting data, analyzing data, and forming conclusions),

- simultaneous inclusion and transformation of data and its analysis by more than one approach.

The planning and scheduling method used and popularized in practice according to the APICS standard [72] treats the problem of planning holistically, process-wise, but leaves the choice of planning tools and methods to managers according to their best knowledge, practice, and needs.

As far as the logistics planning process is concerned, the application of the method of logistics planning in the implementation of the adaptive strategy seems to be justified and is related to the preparation of investment projects, their evaluation, and process 
reengineering according to the best practices of business process reengineering (BPR). The preparation of a logistics plan according to an adaptive strategy should treat the enterprise's logistics system as a process-integrated system processing streams of goods [73,74], taking into account the consumption of energy [75] and environmental resources.

\section{The PL9A Method of Logistics Planning}

The authors of the PL9A method use the enterprise data obtained in the study of the logistics system using the AL9A auditing method. The AL9A method, which has been in practice since 2010, includes the examination of processes [76] together with the systemic identification of engineering, management, and economic mismatches, i.e., bottlenecks.

Table 3 presents basic information relating to the complementary methods and computer applications used in the PL9A logistics planning process.

Table 3. Information on the proper names used in the article: AL9A, PL9A, CL9A, and 9A LOGPLANNER.

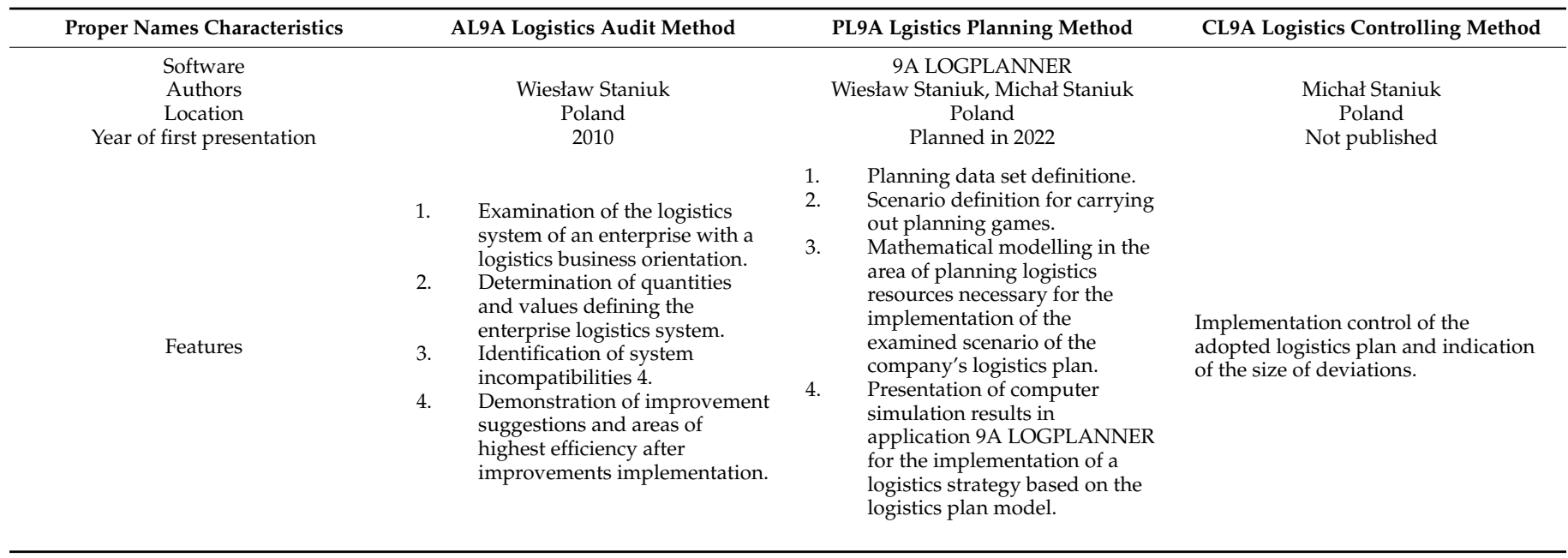

The recognized sub-optimization of the economic and operational efficiency is determined with auditing procedures supported by the AL9A method, allowing the auditors to model the most optimal solutions. As a result, the method is aimed towards stimulating synergy effects between supply, production, and distribution (Figure 3).

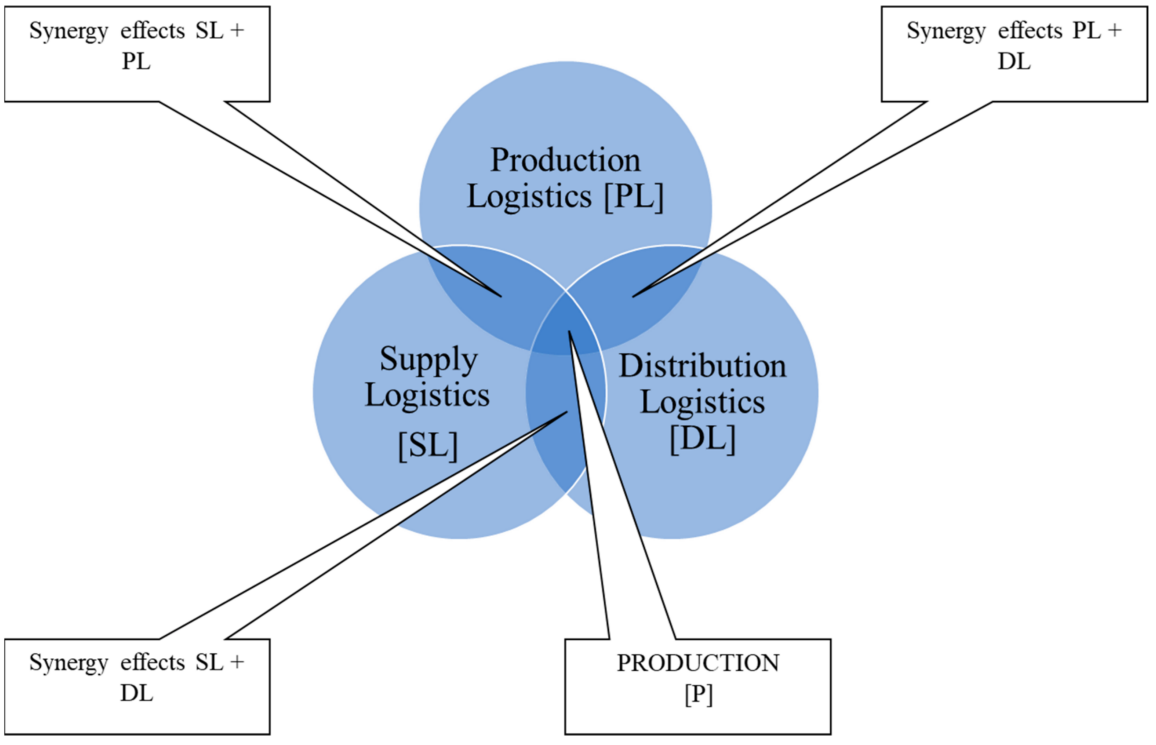

Figure 3. Exploitation areas of synergy effects according to the PL9A method. 
It is worth noting that the AL9A method also includes a study and evaluation of the company in terms of the effectiveness of processes against ecological criteria $[77,78]$ and energy consumption [79]. Particularly important is energy efficiency [80], ecological [81] in transport companies [82,83], food production industries, especially those related to the processes of storing goods in cold stores and freezers. The implementation of the planning process by the PL9A method allows managers to build up a set of sizes of deterministic variables influencing the choice of an appropriate planning strategy.

The PL9A method of logistical planning is based on a process approach to task implementation and includes:

1. Examination of material flow streams.

2. Inventory and study of logistics resources capability.

3. Determination of reference quantities for the designed logistics system.

4. Development of a conceptual design of the logistics system.

5. Determination of a catalog of logistic processes.

6. Conducting mathematical modeling process.

7. Assessment of the logistical system concept.

8. Approval and recommendation for implementation.

The comprehensive logistics planning according to the PL9A method is illustrated in Figure 4 .

AL9A LOGISTICS AUDIT

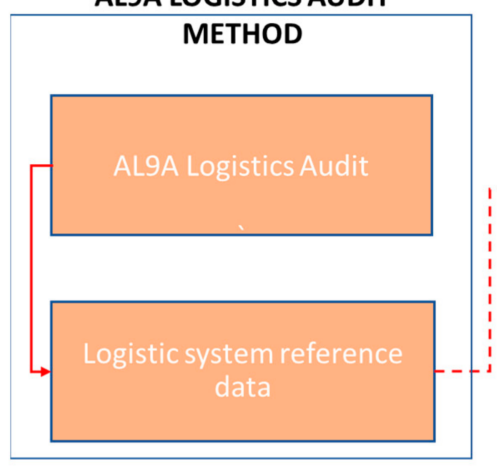

PL9A LOGISTICS PLANNING

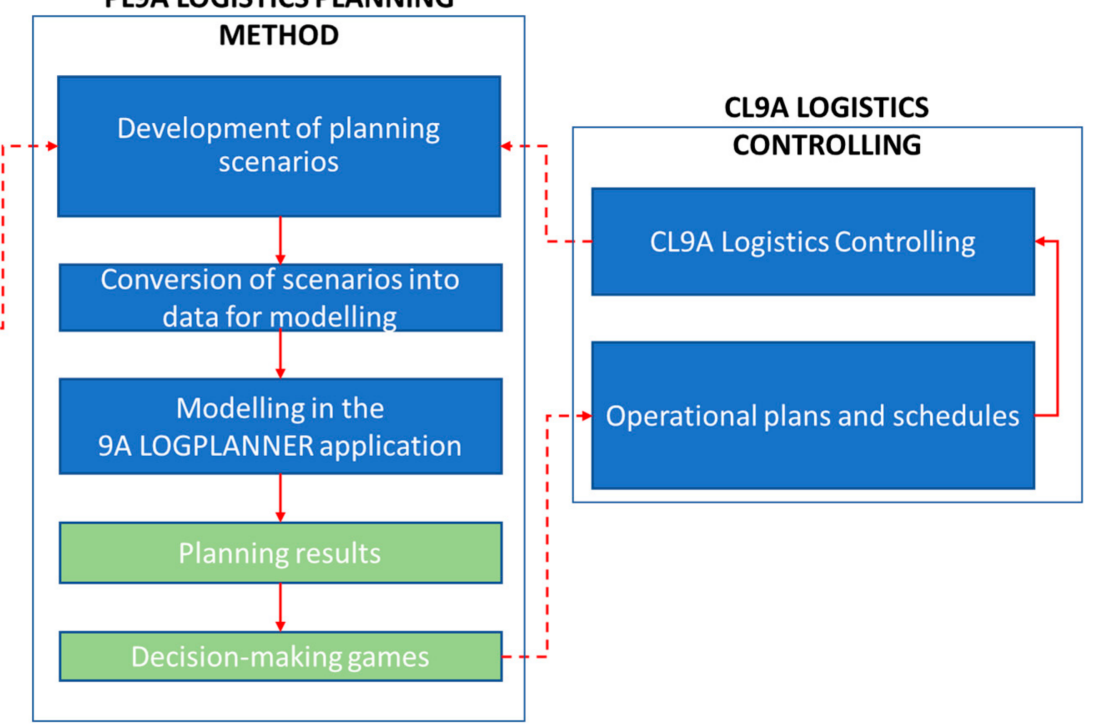

Figure 4. Comprehensive logistics planning according to PL9A method.

Logistics planning according to the PL9A method is initiated by the reference data of the logistics system, acquired via the AL9A audit. Planning scenarios are developed, which are then converted into data for modeling the logistics system. The data is imported into the 9A LOGPLANNER application, in which the logistics system is modeled based on the established scenarios. Depending on the project assumptions and accepted scenarios, the result of the work is a model of the logistic system, further evaluated during decisionmaking games. The selected plan forms the basis for the development of operational plans and schedules. The developed plans and schedules form the basis for the development of procedures for controlling their implementation as part of the CL9A logistics controlling activities. The results and reports of CL9A logistics controlling are directed to the development of planning scenarios for each subsequent logistics planning cycle. A detailed planning process using the PL9A method is shown in Figure 5. 


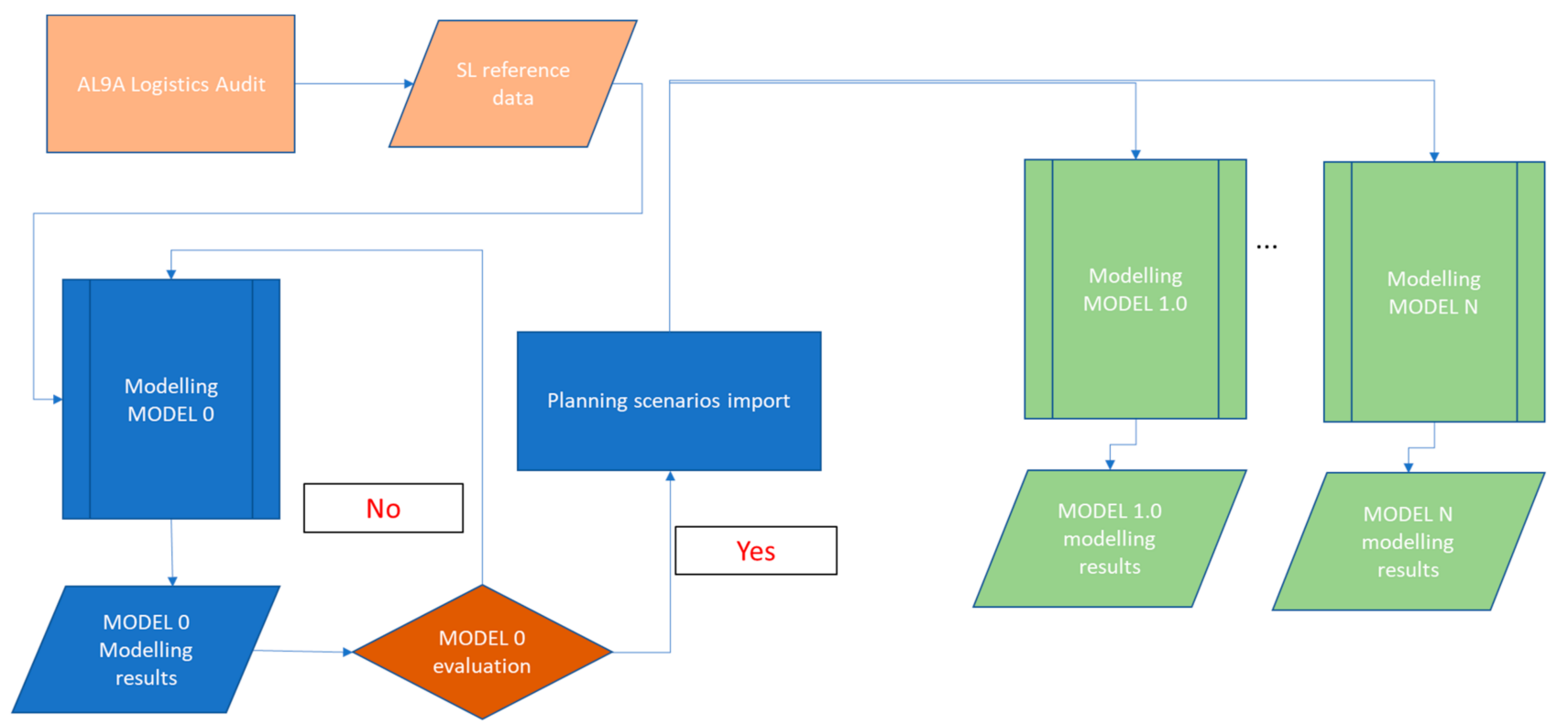

Figure 5. The PL9A planning process.

Based on the reference data, Model 0 is created as a reflection of the company's current logistics system. If the Model 0 does not correspond with the actual state, it is returned to the previous stage, and modifications are made to the planning model. If Model 0 is confirmed as compliant with the actual state, data from the established planning scenarios are imported into 9A LOGPLANNER, which will be used to develop new models of the logistics system. In the 9A LOGPLANNER application, it is possible to create any number of models that differ in physical parameters of cargo units, size of flowing streams of goods, technological equipment and logistics work organization. After the modelling process is completed, results are generated. It forms the basis for the evaluation for the purpose of implementing the scenario into operational activities.

The evaluation criteria contained in the PL9A method can be classified as a group of reference quantities characterizing the logistics system. Such reference quantities of the logistics system should be in a strong relationship with the relevant elements of the logistics planning model. The representation of the relationship is the cause and effect relationship capturing the study of the logistics planning process by the PL9A method, which is shown in Figure 6.

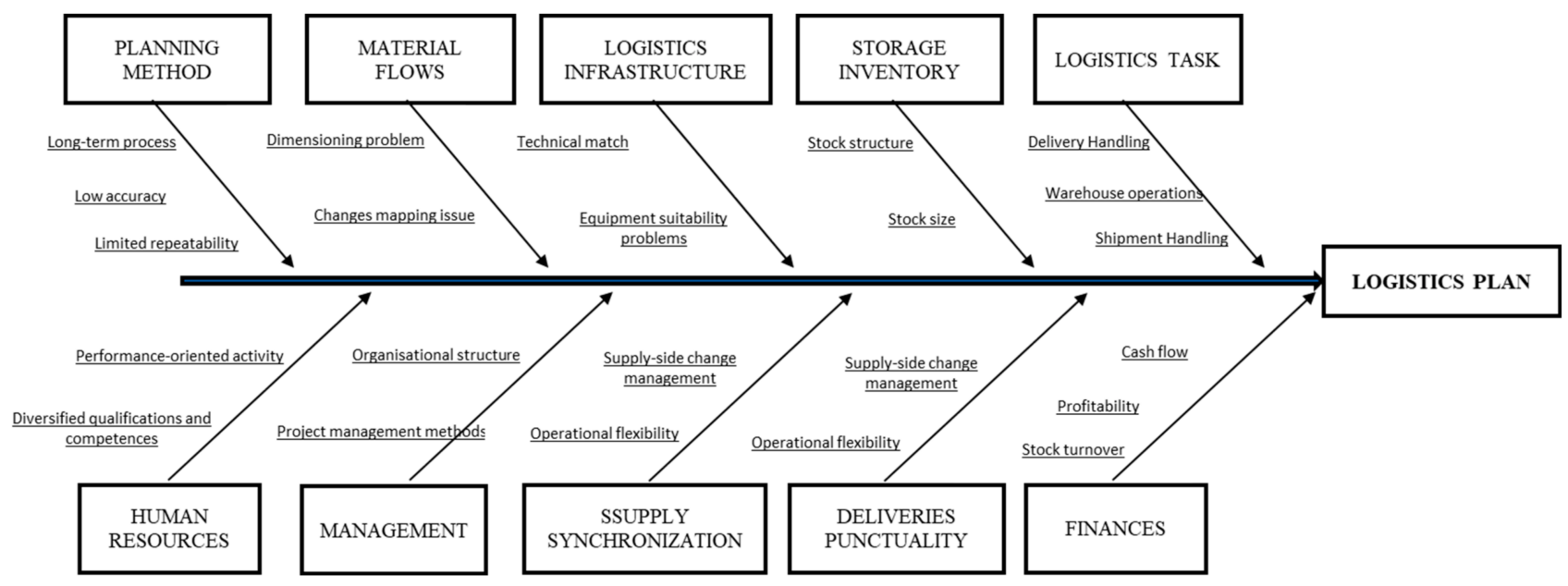

Figure 6. Cause and effect relationship in the evaluation of the logistical planning process using the PL9A method. 
The conducted literature research allowed to determine the barriers in supply chain management and to identify and systematise the cause-effect relationships occurring in the process of logistic planning.

The effects of applying the mathematical modelling method in the process of logistic planning with the use of the PL9A method and the application 9A LOGPLANNER in the research experiment are presented in the next chapter.

\section{Case Study}

The method was tested in a case study of improving logistic processes in a functioning manufacturing company. The experimental research was based on real data obtained from a manufacturing company.

\subsection{Purpose of the Project}

The aim of the project was:

1. To carry out a study of the logistics system of a production plant under the conditions caused by COVID-19,

2. To propose changes in the logistics system.

\subsection{Project Assumptions}

At the project implementation stage, it was assumed that issues of packaging warehouse management were excluded from the study of flowing streams of goods. The implementation of ERP, Warehouse Management System (WMS), and Manufacturing Execution System (MES), IT systems, supporting the management and control of processes, was assumed in the designed models.

\subsection{Project Implementation Tasks}

Taking into account the characteristics of the production plant, the following tasks are envisaged for implementation in the logistic process improvement project:

- Task 1. Auditing the company's logistics system.

- Task 2. Analyzing the effectiveness of the ERP system implementation to support the management of logistics and production.

- $\quad$ Task 3. Analyzing the management system of logistic processes in the production area.

- $\quad$ Task 4. Identifying system mismatches.

- Task 5. Developing a technological and conceptual project for improvement of logistics management and changes in the production-logistics system, including the identification of synergy benefits exploitation sites.

- $\quad$ Task 6. Determining the value of an investment and the size of logistic costs.

\subsection{Research Tools}

The presented steps were conducted using the PL9A method, supported by the AL9A logistic audit and the 9A LOGPLANNER application.

\subsection{Project Implementation}

\subsubsection{Implementation Stage, Task 1: Auditing the Company's Logistics System}

Using the AL9A method of logistics audit [84], planning quantities and reference quantities characterizing the logistics system were determined and it was established that:

1. The storage system is based on stacking block storage.

2. The internal transport system functions based on electrically driven forklifts.

3. The following types of production forms are used in production processes:
a. workstations,
b. production sockets,
c. assembly lines,
d. device processes. 
4. The following methods of logistics management are used in the logistics system:

a. Just in time,

b. Kanban as a production supply system,

c. storage of pallets is executed on storage sites located in the immediate proximity of the input and output zones of the production plant,

d. storage processes for bulky cargo units are carried out at storage areas located in the immediate proximity of the entry zones.

All work at the Task 1 stage was carried out based on:

1. Inventory of logistically significant facilities and resources.

2. Documentation review.

3. Examination of logistical data aggregated in time series registered in the ERP system.

4. Interviews.

5. Examination of warehouse documentation.

6. Arrangements made during workshops.

7. Data from the ERP system, examination of processes and their chronometric contained in the logistical audit report carried out using the AL9A method.

8. Examination of documentation and system procedures in the area of quality management.

The project was initiated by examining the quality and usability of the ERP system implementation, including an assessment of its suitability for the company's future development needs.

In terms of the work covered by Task 1 , the following works were carried out:

1. Inventory of infrastructure components.

2. Identification of logistic processes for each of their phases_sourcing, manufacturing and distribution.

3. Determination of reference quantities characterizing the logistic system according to the AL9A method $[85,86]$.

4. Relational determination of system mismatch:

a. pallet load units - technical equipment,

b. transport processes-logistic processes

c. logistic processes-IT systems,

d. IT systems-management processes,

e. management processes-operational efficiency,

f. operational efficiency-employment in processes,

g. employment in processes-economic efficiency.

Based on the study of the company's logistic system, the logistic system was mapped as Model 0 (interpreted as the initial state). A specialized tool in the form of the 9A LOGPLANNER application was used in the study process.

\subsubsection{Model 0-Representation of the Existing Logistics System}

The logistical system in the supply area was based on block storage supplemented by a local storage system using high racking technology. Transport and manipulation processes were performed using lift trucks. In model 0 , logistic and transport processes in the area of production logistics were realized in the space of the production hall, production buffers were located in the places of separation of main groups of processes. The production buffers were presented in the form of block storage with different surface areas and sizes. Kanban systems were used in the management of production supply processes. Logistics processes in the distribution logistics subsystem in Model 0 were defined as a block storage system in five storage layers.

The transport system is based on the use of front lift trucks. The logistics control system in Model 0 is based on ERP-class IT systems with limited functionalities covering logistics and warehouse management.

For the study, reference quantities of the analyzed logistic system were determined, the structure of which is presented in Table 4. 
Table 4. Structure of reference quantities.

\begin{tabular}{cccc}
\hline No & Group & Logistics System Parameters & Parameter Quantity \\
\hline 1. & Economics & Logistics costs & 21 \\
2. & Investment expenditures & 28 \\
3. & Organization of & Deliveries & 8 \\
4. & work & Shipments & 8 \\
5. & Loading unit & Deliveries & 18 \\
6. & & Shipments & 18 \\
7. & & Management method & 10 \\
8. & Warehouse facility & 20 \\
9. & Technology & Supplementary areas & 23 \\
10. & & Infrastructure parameters & 18 \\
11. & & Storage area & 27 \\
12. & & Inter-area transfers & 15 \\
13. & Logistic task & Deliveries & 6 \\
14. & & Shipments & 6 \\
\hline
\end{tabular}

5.5.3. Implementation Stage, Task 2: Analysing the Effectiveness of the ERP System Implementation to Support the Management of Logistics and Production

This step included:

1. mapping of logistical processes,

2. identification of cost centers,

3. places of registration in the ERP system of data relevant for controlling and managing logistics and production.

The study revealed a mismatch between the information system and the logistics system, which significantly affected the efficiency of processes in the integrated logistics and production system resulting in the following problems:

1. Low tracking accuracy in the logistics and production system.

2. The need for additional work related to the planning of shipments, order picking, completion of shipments, tracking units in the plant space, resulting from the limited data structure in the ERP system.

3. Generating delays in the management processes of planning and controlling processes of order picking and internal transport processes.

4. The need for additional planning activities in spreadsheets.

5. Lack of possibility to control logistic processes using ABC XYZ analysis methods.

The limited functionalities had a significant impact on the labor-intensive planning and control processes. The development of a transport loading plan required additional activities related to confirming the availability of goods, taking into account their quality status.

5.5.4. Implementation Stage, Task 3: Analyzing the Management System of Logistic Processes in the Production Area

The study aimed to determine:

1. Volumes of stocks in the production system.

2. Volumes of flowing streams of goods in a production system.

3. Variability and intensity of transport processes related to production processes.

4. Places of importance from the point of view of quality control system requirements.

\subsubsection{Implementation Stage, Task 4: Identifying System Mismatches}

The task was carried out based on a logistics audit according to the AL9A method. The determination and examination of system mismatch places in combination with the identification of synergy effects exploitation places in the PL9A method serves to determine the quantities and their values necessary to assess the effectiveness of the investment and to determine the ROI. 
The process of determining the mismatch places included the evaluation of the logistics system in the areas:

1. Mismatch in the relationship between the information system and the management and control subsystems.

2. Mismatch in the relationship between goods streams and the warehouse subsystem.

3. Mismatch in the relationship warehouse subsystem and production subsystem.

4. Mismatch in the relationship warehouse subsystem and employment in logistics processes.

5.5.6. Implementation Stage, Task 5: Developing a Technological and Conceptual Project for Improvement of Logistics Management and Changes in the Production-Logistics System, Including the Identification of Synergy Benefits Exploitation Sites

The research at this stage reflects the development of two distinctive models:

1. Model 1 is a concept for the reconstruction of the logistic system including a separation between the production logistics structure and a change in the storage system.

2. Model 2 is a reconstruction concept in which Model 1, where the production logistics structure and the supply logistics structure are integrated.

Details of the logistics system features in Model 1 and Model 2 are shown in Table 5.

Table 5. Logistics system features in Model 1 and Model 2.

\begin{tabular}{|c|c|c|c|}
\hline No & System Traits & Model 1 & Model 2 \\
\hline 1. & Company structure & $\begin{array}{l}\text { Separated structures of production } \\
\text { and supply logistics }\end{array}$ & $\begin{array}{l}\text { Integrated structure of production } \\
\text { and supply logistics }\end{array}$ \\
\hline 2. & Storage devices & Row racking & Row racking \\
\hline 3. & Transport devices & Reach Trucks & Reach Trucks \\
\hline 4. & Supply logistics operational area & To be determined & To be determined \\
\hline 5. & Production logistics operational area & To be determined & To be determined \\
\hline 6. & Distribution logistics operational area & To be determined & To be determined \\
\hline 7. & Capacity of logistic subsystems & As in Model 0 & As in Model 0 \\
\hline 8. & Supply rotation in logistic subsystems & As in Model 0 & As in Model 0 \\
\hline 9. & Cargo streams in logistic subsystems & As in Model 0 & As in Model 0 \\
\hline 10. & System of company management & ERP & ERP \\
\hline 11. & System of managing supply logistics & WMS & WMS \\
\hline 12. & $\begin{array}{l}\text { System of controlling } \\
\text { production logistics }\end{array}$ & WMS & WMS \\
\hline 13. & $\begin{array}{l}\text { System of controlling } \\
\text { distribution logistics }\end{array}$ & WMS & WMS \\
\hline 14. & Production management system & MES & MES \\
\hline 15. & Information circulation & EDI & EDI \\
\hline
\end{tabular}

In the developed models 1 and 2, logistics management and control were based on the integration of the existing ERP system with WMS and MES systems. Management and transport processes for packaging, pallet load unit carriers and waste streams were excluded from the models studied.

The developed logistics system in Model 1 was built by applying high storage technology with the change of transport equipment to high lift trucks. The production logistics structure was separated by creating a production buffer on the surface of the production halls organized in the form of a high storage warehouse. Transport in the production area was based on transport devices serving the entry and exit buffers to nests and workstations. The research objective in Model 1 was to answer the questions:

1. Is there an opportunity to improve the efficiency of the logistics system that would benefit the current state of logistics?

2. If such a possibility exists, what would be the payback period?

Model 2 complements Model 1 by integrating procurement logistics with production logistics. The research objective of Model 2 was to answer the following questions: 
1. Is there a synergy benefit as a result of simplifying procurement procedures and processes integrated into production planning processes?

2. If a synergy benefit is identified, how much benefit can be expected from implementing this change?

5.5.7. Implementation Stage, Task 6: Determining the Value of the Investment and the Size of Logistic Costs

Based on the determined quantities characterizing the logistic system and their infrastructure equipment, the unit costs of acquiring the infrastructure resources were established and the amount of investment outlays was determined. The costs account includes costs related to employment, depreciation, materials, external services, infrastructure maintenance, and IT. The economic evaluation covers only the items of the logistics cost account that are important in terms of cause and effect relations in the logistics system. For the analyzed company the transport costs on the supply and distribution side were excluded from the calculation as they were considered fixed and independent of the modeling results. In the PL9A method, transport costs on the procurement and distribution side are taken into account in the process of modeling and evaluation of the logistics system for cases involving the choice of the location of logistics system facilities.

\subsection{Results of Project Implementation}

The results of the implementation of the project were consolidated into four groups:

Group 1. Relevant parameters.

Group 2. Logistics infrastructure.

Group 3. Investment outlays.

Group 4. Efficiency evaluation of the logistic system

\subsubsection{Group 1: Relevant Parameters}

In the PL9A method of logistics planning, five basic parameters were determined essentially:

1. The logistics task. It includes the identification and dimensioning of the streams of goods and materials flowing through the system aggregated to the reference quantities that characterize the logistical processes of the enterprise.

2. Surface area $\left(\mathrm{m}^{2}\right)$.

3. Cubic capacity $\left(\mathrm{m}^{3}\right)$.

4. Storage capacity. It results from the size of the logistical task and the basic logistical quantities including the stock rotation period expressed in the capacity of conventional pallet loading units (load units).

5. Employment. The total number of persons employed in performing the processes related to the handling of streams is specified in the logistics task of the storage, transport, and handling phase (FTE).

The proposed parameters are related to the elements of the logistics system, which are responsible for the implementation of the basic functions of the enterprise (Figure 7).

All models were parameterized to realize the same logistical task defined as all flows of goods in a logistical system. Model 0, which represents the real state of company logistics, is characterized by more than twice the demand for system space in comparison with Models 1 and 2. The use of high storage racking reduces the demand for cubic capacity of facilities to $30 \%$, which indicates the low effectiveness of block storage in Model 0. Despite the significant difference in cubic capacity, all models are characterized by similar capacity of the logistic system. Model 0 is characterized by the highest demand for human resources necessary to fulfill the defined logistics task. The use of high-bay racks and the integration of production and procurement logistics processes allows for significant optimization of the human resource requirements in Model 1 by up to $40 \%$ compared to Model 0 . The separation of procurement and production logistics functions increases the employment in Model 1 by $10 \%$ compared to Model 2. 


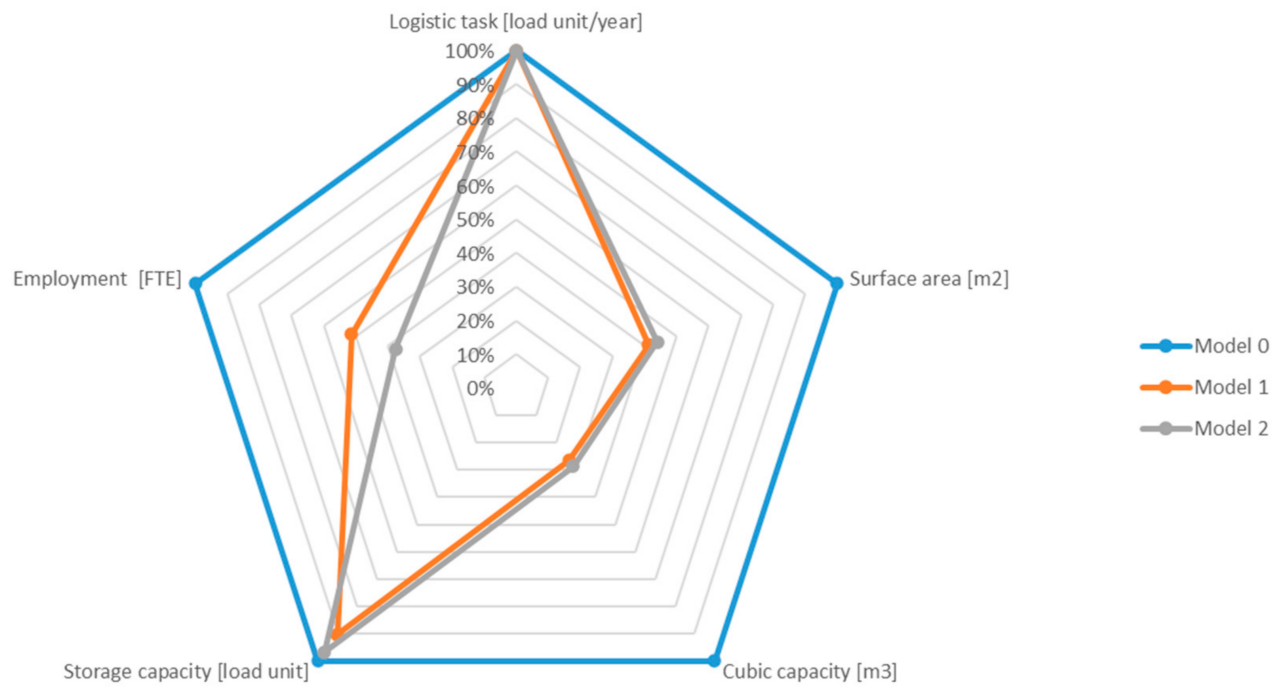

Figure 7. Results of the PL9A modeling of the Logistics System-Group 1-5 main parameters.

\subsubsection{Group 2: Logistics Infrastructure}

In the logistics infrastructure group, four parameters were defined:

1. Internal transport means.

2. Storage facilities.

3. Transfer facilities.

4. Loading docks.

The results of the modeling with the logistics infrastructure criterion are presented in Figure 8.

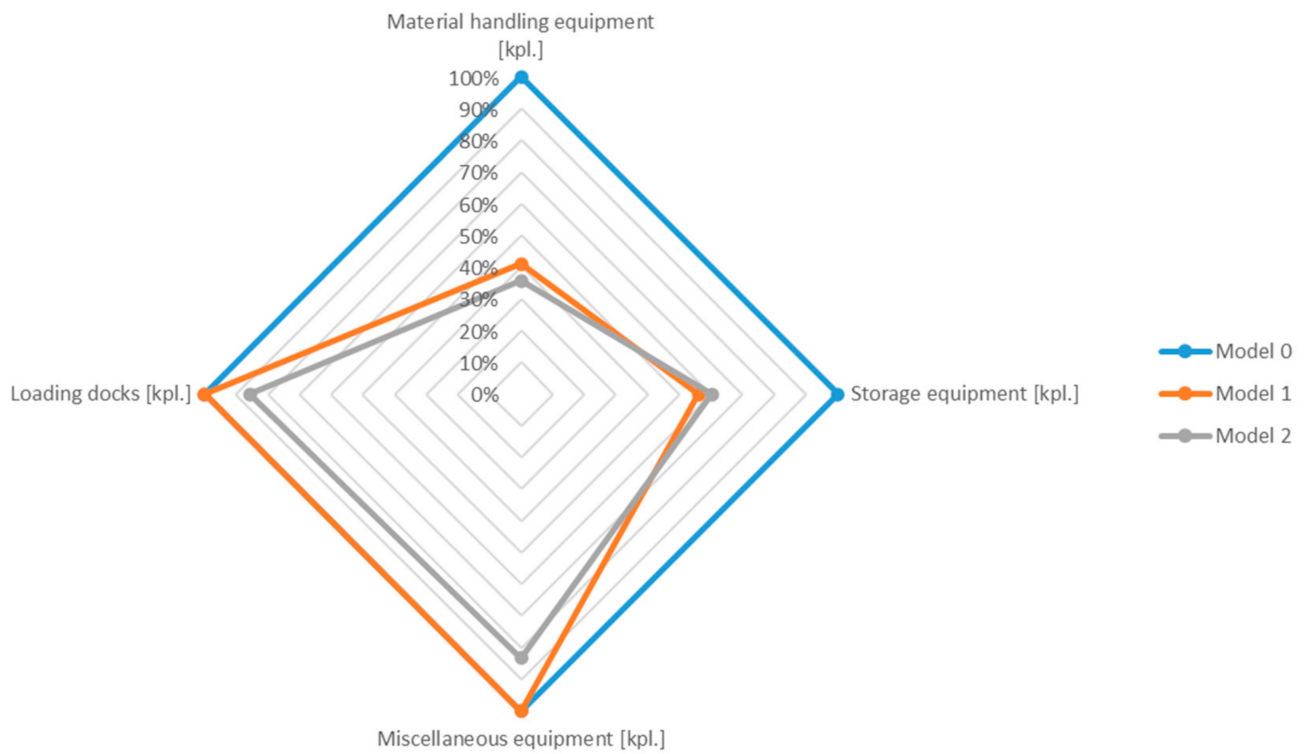

Figure 8. Results of the PL9A modeling of the Logistics System-Group 2-Logistics Infrastructure.

Model 0 has the highest demand for materials handling equipment (Figure 7). The other models reduce the equipment requirements for Model 1 and 2 by $55 \%$ and $60 \%$ respectively, which is correlated with the size of the workforce. In block storage, the demand for the amount of storage equipment-columns, is driven by the size of the assortment. In Models 1 and 2, thanks to the use of high-bay racking and the free storage method, the need for columns is reduced by about $40 \%$. The demand for ancillary equipment is similar in Models 0 and 1.0, but a 15\% reduction is possible due to the integration of supply 
logistics and facility production. The number of loading docks is similar in Models 0 and 1. In Model 2, by integrating procurement logistics and facility production, demand can be optimized by about $12 \%$.

The modeling results for the logistics infrastructure criterion showed that:

1. Model 2 has the lowest need for the number of material handling equipment,

2. Model 1 and 2 have the lowest number of storage facilities,

3. In assessing the number of loading docks and the need for auxiliary equipment, Models 0 and 1 are equivalent and Model 2 has the lowest values for this criterion.

\subsubsection{Group 3: Capital Expenditures}

Three parameters have been defined in the capital expenditure group:

1. Investment expenditure on technological equipment,

2. Investment expenditure on buildings and structures,

3. Total investment expenditure.

The results of the modeling taking into account the investment criterion are presented in Figure 9.

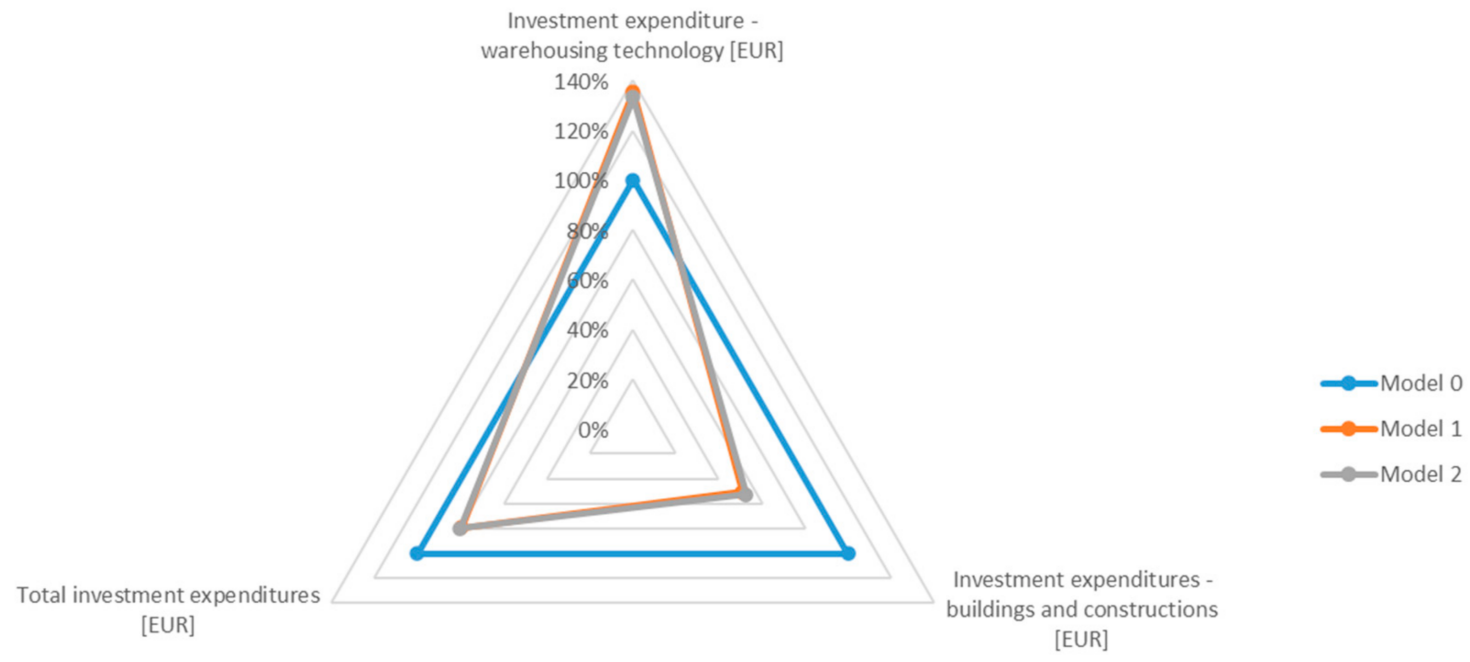

Figure 9. Results of the PL9A modeling of the Logistics System-Group 3-Investment Expenditures.

The use of high-bay racking and dedicated load handling equipment in Models 1 and 2 increases investment in storage technology by $40 \%$ relative to low-cost logistics in Model 0 (Figure 9). Due to increased space requirements, investment in buildings and structures is $40 \%$ higher in Model 0 relative to Models 1 and 2. Total investment in Models 1 and 2 is 20\% lower than low-cost logistics for storage technology in Model 0.

The modeling results for the capital expenditure criterion showed that:

1. The lowest investment outlays focused on technology are characteristic for Model 0.

2. The highest value of investment outlays on the buildings and structures side is characteristic for Model 0.

3. The lowest total investment outlays are characteristic for Models 1 and 2.

5.6.4. Group 4: Evaluation of the Efficiency of the Logistics System

In the group evaluating the efficiency of the logistics system, four parameters were defined:

1. Efficient use of the capacity of the logistics system.

2. Unit cost per pallet unit flowing through the logistics system.

3. Rotation period.

4. Total logistics costs per year.

The results of modeling taking into account the criterion of efficiency assessment of the logistic system are shown in Figure 10. 


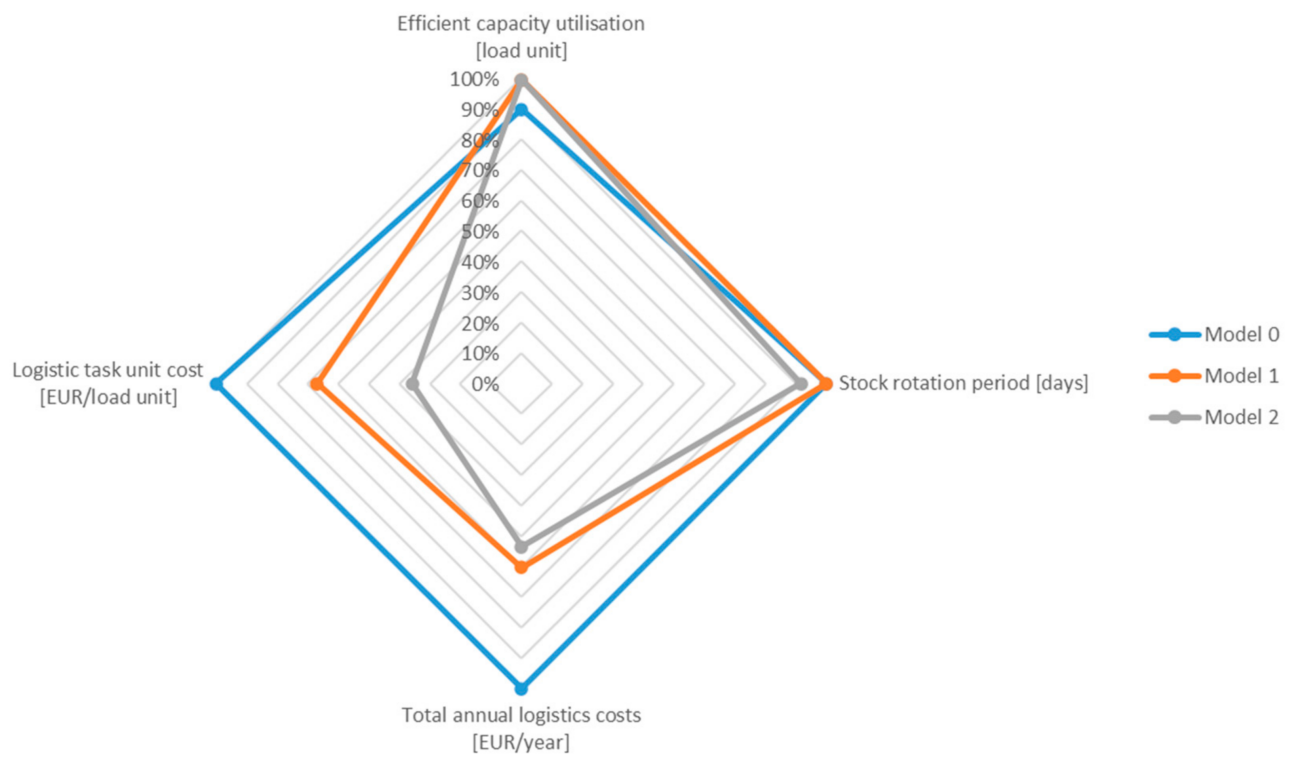

Figure 10. Results of the PL9A modeling of the Logistics System-Group 4-Logistics System Efficiency.

Models 1 and 2 ensure the most effective use of the capacity of the logistical system, which results from the use of the free-storage method (Figure 10). Block storage in Model 0 requires $10 \%$ more logistics system capacity to handle the assumed level of inventory. Models 0 and 1 have the same stock rotation period, while the integration of procurement and production logistics in Model 2 reduces the rotation period by $8 \%$. Model 0 has the highest level of total annual logistics costs. Model 1 reduces logistics costs by $40 \%$ compared to Model 0, while process integration in Model 2 optimizes them by an additional 7\%. Unit logistics costs measured per unit of cargo flow show that the highest costs are found in Model 0 . Model 1 reduces unit costs by 33\% and Model 2 by $64 \%$ compared to Model 0 .

The modeling results showed that Model 0 is the least favorable in all economic evaluation criteria. Model 2 has the lowest unit costs per pallet loading unit flowing through the logistics system. In the assessment of the installed capacity balance and the total volume of stock expressed in capacity units, Model 1 and 2 have the lowest surplus volume.

The final evaluation of the logistics system using the PL9A method of logistics planning also requires consideration of many other criteria, but the analysis of the results clearly shows that:

1. The lowest unit costs for a pallet unit flowing through the logistics system are characteristic of Model 2.

2. The lowest investment expenditures for the construction of logistic infrastructure are characteristic of Model 0.

3. The highest investment expenditures on the construction of technical infrastructure are characteristic of Models 1 and 2.

Taking the above into account, the optimal and recommended solution for a logistics process improvement project is the logistics plan presented in Model 2.

\section{Conclusions}

The PL9A method of logistics planning in combination with the AL9A method of logistics auditing allowed to carry out the process of research, modeling, and development of the company's logistic system change project, leaving the operational level managers, board of directors, and owners adequate time to carry out the project verification, choose the variant and convert it into an investment project with a real and satisfactory period of return. 
The logistics system improvement (optimization) project carried out using the PL9A method includes data verification processes and the presentation of analysis results. The electronic documentation supplemented with analyses, conceptual drawings allows to carry out the logistics design process also in conditions of limited accessibility to cost centers and registration of logistic and economic events. The availability of logistics data arranged in a time series provides consultants and designers with the possibility to determine the quantities and values characterizing the enterprise at a high level of confidence and accuracy.

The 9A LOGPLANNER computer application developed for the implementation of the PL9A method is in the research and improvement phase for analytical tools. Ultimately, it is planned to develop a computer application integrated with ERP and WMS systems and allow the planning process to be conducted at any time based on data aggregated in the systems.

The application of the PL9A method in the analyzed project led to the development of a project to improve logistic processes in a functioning enterprise. The method was tested in the conditions of the functioning of enterprises in the lockdown mode related to the occurrence of the COVID-19 pandemic, where $90 \%$ of the work was carried out remotely.

The PL9A method of logistics planning presented in this study makes it possible to carry out modeling and simulations in a short time, with limited involvement and the burden of additional duties of operational level managers. Determination of the quantities characterizing the logistics system of the enterprise was carried out based on the study of records of economic events aggregated in time series, as well as an inventory of resources and process mapping.

Embedding the logistics planning process in a computer application shortens the process of modeling and developing the logistics plan with limited time expenditure. Thus, the impact of risks on the quality of the planning process is reduced, in particular:

1. Risk of lack of scalability of data.

2. Risk of lack of data consistency.

3. Risk of time impact on reasoning process and decision accuracy.

4. Risk of the decision-making process resulting from managing distributed, multiprocessed data in a complex IT environment.

Energy and ecological efficiency in logistics planning according to the PL9A method can be seen in:

1. Optimization of the area and volume of facilities including energy intensity:

a. lighting system,

b. the heating system,

c. the ventilation system,

d. cooling system.

2. Optimize the number of materials handling equipment.

3. Optimize the size and structure of the inventory.

4. Reduce losses resulting from limited possibilities to react quickly to changes in demand and supply.

5. Shorten the reaction time for changes.

The problem of efficiency of enterprises raised by many authors, including its energy intensity and ecology and supply chains in general, focuses on the methods of management inside the organization in the here and now, studying past states and approximating them to infer and predict the future, taking into account the volatility of the environment. In practice, companies face the challenges of managing a supply chain open to opportunities and threats, at a time when their level of development, size, management methods, and regulatory environment make it labor-intensive, questionable in terms of reliability, and a significant challenge. When analyzing the impact of the COVID-19 pandemic on social and economic change and the impact on business, it should be noted that the problem of adaptation of businesses to changing conditions will arise when the determining factor 
of COVID-19 ceases to exist or when a new factor emerges. In these circumstances, the adaptability of enterprises cooperating in supply chains acquires a new significance.

Author Contributions: Conceptualization, W.S., M.S., N.C.-G., M.J. and M.K.; methodology, W.S., M.S. and N.C.-G.; software, W.S. and M.S.; validation, W.S., M.S., N.C.-G., M.J. and M.K.; formal analysis, W.S. and M.S.; resources, W.S. and M.S.; data curation, W.S., M.S. and N.C.-G.; writingoriginal draft preparation, W.S., M.S. and N.C.-G.; writing-review and editing, W.S., M.S. and N.C.-G. and M.K.; visualization, W.S. and M.S.; supervision, M.K., M.J. and N.C.-G.; funding acquisition, M.J. and M.K. All authors have read and agreed to the published version of the manuscript.

Funding: The paper was co-financed by the Scientific Council of the Civil Engineering and Transport at the Warsaw University of Technology.

Intellectual Property Rights: The intellectual property rights for the name, method and application in the form of the 9A LOGPLANNER, PL9A Logistics Planning, AL9A Logistics Audit and CL9A Logistics Controlling is held by M. Staniuk and W. Staniuk.

Institutional Review Board Statement: Not applicable.

Informed Consent Statement: Informed consent was obtained from all subjects involved in the study.

Data Availability Statement: Data available in a publicly accessible repository.

Acknowledgments: The authors would like to gratefully acknowledge the reviewers that provided helpful comments and insightful suggestions on a draft of the manuscript.

Conflicts of Interest: The authors declare no conflict of interest. The funders had no role in the design of the study; in the collection, analyses, or interpretation of the data; in the writing of the manuscript; or in the decision to publish the results.

\section{References}

1. Chopra, S.; Meindl, P. Supply Chain Management: Strategy, Planning and Operation (Global Edition); Pearson Education Limited: Boston, MA, USA, 2013.

2. APICS. Exploring the Big Data Revolution; APICS: Chicago, IL, USA, 2015.

3. Hinojosa-Palafox, E.A.; Rodriguez-Elias, O.M.; Hoyo-Montano, J.A.; Pacheco-Ramirez, J.H.; Nieto-Jalil, J.M. An Analytics Environment Architecture for Industrial Cyber-Physical Systems Big Data Solutions. Sensors 2021, 21, 4282. [CrossRef]

4. Cech, M.; Lenort, R. Modelling of financial resource allocation for increasing the supply chain resilience using markov chains. Acta Logist. 2021, 8, 141-151. [CrossRef]

5. Woźniak, W.; Jakubowski, J. The choice of the cost calculation concept for the mass production during the implementation of the non-standard orders. In Proceedings of the 26th International Business Information Management Association ConferenceInnovation Management and Sustainable Economic Competitive Advantage: From Regional Development to Global Growth, IBIMA 2015, Madrit, Spain, 11-12 November 2015; Volume 2015, pp. 2364-2371.

6. Kostrzewski, M.; Chamier-Gliszczynski, N.; Królikowski, T. Selected reflections on formal modeling in Industry 4.0. Procedia Comput. Sci. 2020, 176, 3293-3300. [CrossRef]

7. Kostrzewski, M.; Kosacka-Olejnik, M.; Werner-Lewandowska, K. Assessment of innovativeness level for chosen solutions related to Logistics 4.0. Procedia Manuf. 2019, 38, 621-628. [CrossRef]

8. Ingalls Ricki, G. Wprowadzenie do Symulacji Łańcucha Dostaw, Materiały z Konferencji Winter Simulation; Szkoła Inżynierii Przemysłowej i Zarządzania, Oklahoma State University Stillwater: Stillwater, OK, USA, 2014.

9. Mrugalska, B.; Ahmed, J. Organizational Agility in Industry 4.0: A Systematic Literature Review. Sustainability $2021,13,8272$. [CrossRef]

10. Bukova, B.; Brumercikova, E.; Cerna, L.; Droździel, P. The Position of Industry 4.0 in the Worldwide Logistics Chains. LOGI-Sci. J. Transp. Logist. 2018, 9, 18-23. [CrossRef]

11. Puka, R.; Skalna, I.; Stawowy, A.; Duda, J.; Karkula, M. Decision rules-based method for dynamic adjustment of Min-Max ordering levels. Appl. Soft Comput. 2021, 107, 107370. [CrossRef]

12. Izdebski, M.; Jacyna-Gołda, I.; Golebiowski, P.; Plandor, J. The optmization tool supporting supply chain management in the multi-criteria approach. Arch. Civ. Eng. 2020, 66, 505-524. [CrossRef]

13. Straka, M.; Khouri, S.; Lenort, R.; Besta, P. Improvement of logistics in manufacturing system by the use of simulation modelling: A real industrial case study. Adv. Prod. Eng. Manag. 2020, 15, 18-30. [CrossRef]

14. Kielec, R.; Sasiadek, M.; Woźniak, W. Adaption of the evolutionary algorithm to automate the scheduling of the production processes. In Proceedings of the 31st International Business Information Management Association Conference-Innovation Management and Education Excellence through Vision 2020, IBIMA 2018, Milan, Italy, 25-26 April 2018; Volume 2018, pp. 5039-5046. 
15. Nawrocki, W.; Stryjski, R.; Woźniak, W.; Jakubowski, J. Improving the quality of manufacturing processes in Toyota motor manufacturing, Poland. In Proceedings of the 31st International Business Information Management Association ConferenceInnovation Management and Education Excellence through Vision 2020, IBIMA 2018, Milan, Italy, 25-26 April 2018; Volume 2018, pp. 5931-5945.

16. Zwolińska, B.; Tubis, A.; Chamier-Gliszczynski, N.; Kostrzewski, M. Personalization of the MES system to the needs of highly variable production. Sensors 2020, 20, 6484. [CrossRef]

17. Available online: https://www.pwc.pl/pl/publikacje/2017/przemysl-4-0.html (accessed on 5 December 2021).

18. Królikowski, T.; Ubowska, A. TISAX-Optimization of IT risk management in the automotive industry. Procedia Comput. Sci. 2021, 192, 4259-4268. [CrossRef]

19. Jelonek, D. Paradoks produktywności technologii informacyjnych z perspektywy me-nedżerów (The paradox of information technology productivity from the perspective of managers). Prace Uniwersytetu Ekonomicznego Wrocławiu 2016, 421, 205-215. [CrossRef]

20. Herden, T.; Nitsche, B.; Gerlach, B. Pokonywanie barier w łańcuchu dostaw Analytics-badanie środków w Organizacje LSCM. Logistics 2020, 4, 5. Available online: https:/ / www.mdpi.com/2305-6290/4/1/5 (accessed on 5 December 2021). [CrossRef]

21. Jacyna-Gołda, I.; Lewczuk, K. The method of estimating dependability of supply chain elements on the base of technical and organizational redundancy of process. Eksploat. Niezawodn. 2017, 19, 382-392. [CrossRef]

22. Souza, G.C. Supply chain analytics. Bus. Horiz. 2014, 57, 595-605. [CrossRef]

23. Wang, G.; Gunasekaran, A.; Ngai, E.W.T.; Papadopoulos, T. Big data analytics in logistics and supply chain management: Certain investigations for research and applications. Int. J. Prod. Econ. 2016, 176, 98-110. [CrossRef]

24. Chae, B.K.; Yang, C.; Olson, D.; Sheu, C. The impact of advanced analytics and data accuracy on operational performance: A contingent resource based theory (RBT) perspective. Decis. Support Syst. 2014, 59, 119-126. [CrossRef]

25. Trkman, P. The critical success factors of business process management. Int. J. Inf. Manag. 2010, 30, 125-134. [CrossRef]

26. Sanders, N.R. How to Use Big Data to Drive Your Supply Chain. Calif. Manag. Rev. 2016, 58, 26-48. [CrossRef]

27. Lai, Y.; Sun, H.; Ren, J. Understanding the determinants of big data analytics (BDA) adoption in logistics and supply chain management. Int. J. Logist. Manag. 2018, 29, 676-703. [CrossRef]

28. Schoenherr, T.; Speier-Pero, C. Data Science, Predictive Analytics, and Big Data in Supply Chain Management: Current State and Future Potential. J. Bus. Logist. 2015, 36, 120-132. [CrossRef]

29. Kache, F.; Seuring, S. Challenges and opportunities of digital information at the intersection of Big Data Analytics and supply chain management. Int. J. Oper. Prod. Manag. 2017, 37, 10-36. [CrossRef]

30. Richey, R.G.; Morgan, T.R.; Lindsey-Hall, K.; Adams, F.G. A global exploration of Big Data in the supply chain. Int. J. Phys. Distrib. Logist. Manag. 2016, 46, 710-739. [CrossRef]

31. Christopher, M. Logistics E Supply Chain Management; Financial Times Prentice Hall: New York, NY, USA, 2011.

32. Nitsche, B.; Durach, C.F. Much discussed, little conceptualized: Supply chain volatility. Int. J. Phys. Distrib. Logist. Manag. 2018, 48, 866-886. [CrossRef]

33. Brinch, M.; Stentoft, J.; Jensen, J.K.; Rajkumar, C. Practitioners understanding of big data and its applications in supply chain management. Int. J. Logist. Manag. 2018, 29, 555-574. [CrossRef]

34. Oliveira, M.P.V.D.; McCormack, K.; Trkman, P. Business analytics in supply chains-The contingent effect of business process maturity. Expert Syst. Appl. 2012, 39, 5488-5498. [CrossRef]

35. Zhu, S.; Song, J.; Hazen, B.T.; Lee, K.; Cegielski, C. How supply chain analytics enables operational supply chain transparency. Int. J. Phys. Distrib. Logist. Manag. 2018, 48, 47-68. [CrossRef]

36. Ramanathan, R.; Philpott, E.; Duan, Y.; Cao, G. Adoption of business analytics and impact on performance: A qualitative study in retail. Prod. Plan. Control 2017, 28, 985-998. [CrossRef]

37. Srinivasan, R.; Swink, M. An Investigation of Visibility and Flexibility as Complements to Supply Chain Analytics: An Organizational Information Processing Theory Perspective. Prod. Oper. Manag. 2018, 27, 1849-1867. [CrossRef]

38. Trkman, P.; McCormack, K.; De Oliveira, M.P.V.; Ladeira, M.B. The impact of business analytics on supply chain performance. Decis. Support Syst. 2010, 49, 318-327. [CrossRef]

39. Hazen, B.T.; Boone, C.A.; Ezell, J.D.; Jones-Farmer, L.A. Data quality for data science, predictive analytics, and big data in supply chain management: An introduction to the problem and suggestions for research and applications. Int. J. Prod. Econ. 2014, 154, 72-80. [CrossRef]

40. Wixom, B.H.; Yen, B.; Relich, M. Maximizing Value from Business Analytics. MIS Q. Exec. 2013, 12, 111-123.

41. Watson, H.J. Tutorial: Big Data Analytics: Concepts, Technologies, and Applications. Commun. Assoc. Inf. Syst. 2014, 34, 1247-1268. [CrossRef]

42. Lavalle, S.; Lesser, E.; Shockley, R.; Hopkins, M.S.; Kruschwitz, N. Big Data, Analytics and the Path from Insights to Value. MIT Sloan Manag. Rev. 2011, 52, 21-32.

43. Dutta, D.; Bose, I. Managing a big data project: The case of Ramco cements limited. Int. J. Prod. Econ. 2015, 165, 293-306. [CrossRef]

44. Ransbotham, S.; Kiron, D.; Prentice, P.K. Minding the Analytics Gap. MIT Sloan Manag. Rev. 2015, 56, 63-68.

45. Roßmann, B.; Canzaniello, A.; Von der Gracht, H.; Hartmann, E. The future and social impact of Big Data Analytics in Supply Chain Management: Results from a Delphi study. Technol. Forecast. Soc. Chang. 2018, 130, 135-149. [CrossRef] 
46. Ross, J.W.; Beath, C.M.; Quaadgras, A. You May Not Need Big Data after All. Havard Bus. Rev. 2013, 91, 90-98.

47. Seddon, P.B.; Constantinidis, D.; Tamm, T.; Dod, H. How does business analytics contribute to business value? Inf. Syst. J. 2017, 27, 237-269. [CrossRef]

48. McAfee, A.; Brynjolfsson, E. Big data: The management revolution. Havard Bus. Rev. 2012, 90, 60-68.

49. Marchand, D.A.; Peppard, J. Why IT fumbles analytics. Havard Bus. Rev. 2013, 91, 104-112.

50. Bose, R. Advanced analytics: Opportunities and challenges. Ind. Manag. Data Syst. 2009, 109, 155-172. [CrossRef]

51. Barton, D.; Court, D. Making advanced analytics work for you. Havard Bus. Rev. 2012, 90, 78-83.

52. Cao, G.; Duan, Y.; Li, G. Linking Business Analytics to Decision Making Eectiveness: A Path Model Analysis. IEEE Trans. Eng. Manag. 2015, 62, 384-395. [CrossRef]

53. Ghasemaghaei, M.; Hassanein, K.; Turel, O. Increasing firm agility through the use of data analytics: The role of fit. Decis. Support Syst. 2017, 101, 95-105. [CrossRef]

54. Simchi-Levi, D.; Simchi-Levi, E.; Kaminsky, P. Designing and Managing the Supply Chain: Concepts, Strategies, and Cases, 3rd ed.; McGraw-Hill New York: Boston, MA, USA, 2003.

55. Brynjolfsson, E. The productivity paradox of information technology. Commun. ACM 1993, 36, 66-77. [CrossRef]

56. Holsapple, C.; Lee-Post, A.; Pakath, R. A unified foundation for business analytics. Decis. Support Syst. 2014, 64, 130-141. [CrossRef]

57. Lewczuk, K.; Kłodawski, M. Logistics information processing systems on the threshold of IoT. Sci. J. Sil. Univ. Technology. Ser. Transp. 2020, 107, 85-94. [CrossRef]

58. Bracht, U.; Geckler, D.; Wenzel, S. Digitale Fabrik: Methoden und Praxisbeispiele, 2nd ed.; Springer: Berlin/Heidelberg, Germany, 2018

59. Schenk, M.; Wirth, S.; Müller, E. Factory Planning Manual. Situation-Driven Production Facility Planning; Springer: Berlin, Germany, 2010.

60. Saihi, A.; Awad, M.; Ben-Daya, M. Quality 4.0: Leveraging Industry 4.0 technologies to improve quality management practices-a systematic review. Int. J. Qual. Reliab. Manag. 2021, 12-24. [CrossRef]

61. Arm, J.; Benesl, T.; Marcon, P.; Bradac, Z.; Schroder, T.; Belyaev, A.; Werner, T.; Braun, V.; Kamensky, P.; Zezulka, F.; et al Automated design and integration of asset administration shells in components of industry 4.0. Sensors 2021, 21, 2004. [CrossRef]

62. Lenort, R.; Stas, D.; Holman, D.; Wicher, P. A3 Method as Powerful Tool for Searching and Implementing Green Innovations in an Industrial Company Transport. Procedia Eng. 2017, 192, 533-538. [CrossRef]

63. Lorenc, A.; Szkoda, M.; Szarata, A.; Jacyna-Gołda, I. Evaluation of the effectiveness of methods and criteria for product classification in the warehouse. Eur. J. Ind. Eng. 2020, 14, 147-164. [CrossRef]

64. Szczepański, E.; Jachimowski, R.; Izdebski, M.; Jacyna-Gołda, I. Warehouse location problem in supply chain designing: A simulation analysis. Arch. Transp. 2019, 50, 101-110. [CrossRef]

65. Tubis, A.A.; Ryczynski, J.; Zurek, A. Risk Assessment for the Use of Drones in Warehouse Operations in the First Phase of Introducing the Service to the Market. Sensors 2021, 21, 6713. [CrossRef] [PubMed]

66. Zelenko, Y.; Bezovska, M.; Kuznetsov, V.; Muntian, A. Technological and Ecological Aspects of Disposal of Spent Cutting Fluids. J. Ecol. Eng. 2021, 22, 207-212. [CrossRef]

67. Gabrylewicz, I.; Lenort, R.; Wedrychowicz, M.; Krupa, P.; Wozniak, W. Environmental Loads Resulting from Manufacturing Technology. Rocz. Ochr. Srodowiska 2021, 23, 613-628. [CrossRef]

68. Zajac, P.; Rozic, T. Energy consumption of forklift versus standards, effects of their use and expectations. Energy 2022, $239,122187$. [CrossRef]

69. Jacyna, M.; Semenov, I. Models of vehicle service system supply under information uncertainty. Eksploatacja Niezawodność 2020 22, 694-704. [CrossRef]

70. Dyczkowska, J. CSR in TSL companies. Transp. Probl. 2015, 10, 97-104. [CrossRef]

71. Jacyna-Gołda, I.; Kłodawski, M.; Lewczuk, K.; Łajszczak, M.; Chojnacki, T.; Siedlecka-Wójcikowska, T. Elements of perfect order rate research in Logistics chains. Arch. Transp. 2019, 49, 25-35. [CrossRef]

72. MPM sp. z o.o. Szczegótowe Planowanie i Harmonogramowanie wg. Standardu APICS; MPM ProdAction sp. z o.o.: Poznań, Poland, 2011.

73. Hammer, M.; Champy, J. Reengineering w Przedsiębiorstwie; Neumann Management Institute: Warszawa, Poland, 1996.

74. Tubis, A.A.; Werbinska-Wojciechowska, S. Influence of transportation services performance on supply chains safety. In Proceedings of the 8th Carpathian Logistics Congress on Logistics, Distribution, Transport and Management CLC 2018, Prague, Czech Republic, 3-5 December 2019; Tanger Ltd.: Ostrava, Czech Republic, 2019; pp. 902-907.

75. Zajac, P.; Kwasniowski, S. Zero Energy buildings in the Logistics warehouse systems. E3S Web Conf. 2017, 22, 00198. [CrossRef]

76. Zwolinska, B.; Tubis, A.A. The algorithm of developing priorities in the supply chain. LogoForum 2020, 16, 333-345. [CrossRef]

77. Jacyna, M.; Wasiak, W.; Lewczuk, K.; Karon, G. Noise and environmental pollution from transport: Decisive problems in developing ecologically efficient transport systems. J. Vibroengineering 2017, 19, 5639-5655. [CrossRef]

78. Reshetnikova, O.; Dyczkowska, J.; Olkiewicz, M.; Paszkowska, D. Promoting Pro-ecological Behavior with Logistics Operators in Poland and Ukraine. Rocz. Ochr. Srodowiska 2021, 23, 642-654. [CrossRef]

79. Staniuk, W. Wieloaspektowa ocena systemu logistycznego przedsiębiorstwa w łańcuchu dostaw na przykładzie metodologii Audit 9A. Logistyka 2012, 4, 687-696.

80. Lewczuk, K.; Kłodawski, M.; Gepner, P. Energy consumption in a distributional warehouse: A practical case study for different warehouse technologies. Energies 2021, 14, 2709. [CrossRef] 
81. Domaga, J.; Zych-Lewandowska, M. Environmental Costs Generated by Road Freight Transport in Poland. Rocz. Ochr. Srodowiska 2021, 23, 138-150. [CrossRef]

82. Tkaczyk, S. The problem pf reducing consumption of stretch film used to secure palletized loads. Rocz. Ochr. Srodowiska 2020, 22, 359-375.

83. Tucki, K.; Orynycz, O.; Mruk, R.; Swic, A.; Botwinska, K. Modeling of Biofuel's Emissivity for Fuel Choice Management. Sustainability 2019, 11, 6842. [CrossRef]

84. Chamier-Gliszczyński, N.; Staniuk, W.; Staniuk, M. Problematyka wskaźnikowej oceny systemu logistycznego w aspekcie koncepcji audytu logistycznego 9A (The issue of indicative assessment of the Logistics system in the aspect of the conception of Logistics Audit 9A). Pr. Nauk. Politech. Warsz. Transp. 2018, 120, 49-58.

85. Filin, S.; Filina-Dawidowicz, L. Improvement of criteria for assessing the energy efficiency of thermoelectric refrigerators used in supply chains. Energies 2021, 14, 1620. [CrossRef]

86. Chamier-Gliszczynski, N.; Staniuk, M. Logistics Audit 9A in the Assessment of Supply Chain Efficiency of Companies Operating in the Industry 4.0. In Proceedings of the 8th Carpathian Logistics Congress CLC 2018, Prague, Czech Republic, 3-5 December 2018; Tanger Ltd.: Ostrava, Czech Republic, 2019; pp. 482-487. 